\title{
Tiedelehti on vireä ja kriittinen yhteisö
}

Tiedelehti rakentaa yhteistä ymmärrystä tieteestä ja sen käytännöistä yhteiskunnassa. Miten päätoimittajat

ovat kokeneet Aikuiskasvatuksen tehtävän?

\section{"Tutkimuksen edelläkävijä edistää avointa tiede- julkaisemista ja tutkimukseen perustuvaa ymmärrystä"}

\section{ULPUKKA ISOPAHKALA-BOURET PÄÄTOIMITTAJA VUODESTA 2019 LÄHTIEN \\ Kasvatustieteen tohtori Ulpukka Isopahkala-Bouret on kasvatus- tieteen professori Turun yli- opistossa ja aikuiskasvatustieteen dosentti Helsingin yliopistossa.}

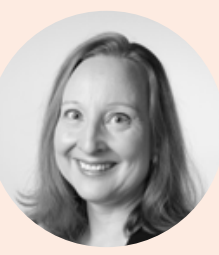

1 Kolme teemaa on noussut ylitse muiden. Ensinnäkin esillä on ollut ekososiaalinen sivistys ja siihen kytköksissä olevat kysymykset. Teemasta on ilmestynyt useita artikkeleita, joista yksi palkittiin kauteni alussa vuoden 2018 tiedeartikkelina. Aiheesta on julkaistu kasvatusfilosofinen pohdinta monilajisesta empatiasta, ja työn alla on kesäkuussa ilmestyvä teemanumero vapaasta sivistystyöstä planetaaristen kriisien aikakaudella.

Toisena teemana on ajankohtaisuutensa vuoksi näkynyt aikuisten maahanmuuttajien koulutus. Kolmas teema tai pikemminkin trendi on moniammatillisuus ja monitieteisyys aikuisten korkea-asteen koulutuksessa.

2 Olen pääkirjoituksissani pyrkinyt herättämään keskustelua tieteenalastamme korostamalla muun muassa avoimen tieteen ja tiedeviestinnän mahdollisuuksia, tulevaisuusorientaation merkitystä ja tutkimuksen painoarvon vahvistamispyrkimyksiä. Olen edistänyt aikuiskasvatuksen yhteiskunnallista näkökulmaa ja keskustelua aikuiskoulutuspolitiikasta. Aiheesta julkaistiinkin runsas ja monipuolinen teemanumero $4 / 2020$. 
1 Mitkä teemat korostuivat päätoimittajakaudellasi? 2 Miten edistit päätoimittajakaudellasi

tieteenalasta käytävää keskustelua? 3 Mihin Aikuiskasvatus-lehteä tarvitaan?

3 Tieteenalan ainoana kotimaisena tiedelehtenä Aikuiskasvatuksen tulee olla alansa tutkimuksen edelläkävijä sekä edistää avointa tiedejulkaisemista ja tutkimukseen perustuvaa ymmärrystä. Lehdessä mahdollistuu tieteellinen vuoropuhelu, jolloin voi syntyä ymmärrystä yksittäisiä tutkimuksia laajemmista ilmiöistä. Tieteen sisäinen keskustelu ja yhteiskunnallinen keskustelu tutkittavista ilmiöistä eivät ole toistensa vastakohtia, vaan tutkittua tietoa lisäämällä voidaan viitoittaa päätöksentekoa ja käytännön työn kehittämistä. Aikuiskoulutuksen ammattilaisia lehti auttaa hahmottamaan oman toiminnan reunaehtoja.

\section{PÄÄTOIMITTAJAN VALINTA}

Kriittisessä artikkelissaan Hanna Laalo ja Arto Jauhiainen tarkastelevat yliopistokoulutukseen jalkautunutta yrittäjämäisyyttä, jonka myötä taloudelliset ja työelämälähtöiset päämäärät korostuvat perinteisten akateemisten ideaalien kustannuksella. Aikuiskasvatus tieteenalana muovautuu osana ja osaksi tätä murrosta. Kirjoittajat herättelevätkin lukijan pohtimaan, mitä tapahtuu akateemisen vapauden, luovuttamattoman kriittisyyden, tutkimuksen riippumattomuuden ja tieteen itseisarvon periaatteille uudessa yrittäjämäisessä yliopistossa. Pohdintaa voi jatkaa kysymällä, minkälaista aikuiskasvatuksen tutkimusta on mahdollista tehdä näissä oloissa.

Laalo, H., \& Jauhiainen, A. (2019).

Yrittäjyyttä akatemiaan! Suomalaisen yliopistokoulutuksen problematisoituminen yrittäjyysdiskurssissa. Aikuiskasvatus 39(2), 92-107. https://doi.org/10.33336/ aik.82983

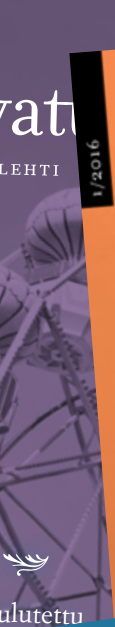

\section{Aikuiskasvatus}

\section{RAJOIA RIKKOVA TIEDELEHTI}

iiskasvatus

\section{Aikuiska:}

OJA RIKKONA TIEDELEHTI
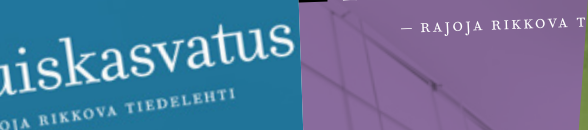
1 Mitkä teemat korostuivat päätoimittajakaudellasi? 2 Miten edistit päätoimittajakaudellasi tieteenalasta käytävää keskustelua? 3 Mihin Aikuiskasvatus-lehteä tarvitaan?

\section{"Keskusteleva julkaisuprosessi parantaa tiedeartikkeleiden}

\section{laatua"}

\author{
HEIKKI SILVENNOINEN \\ PÄÄTOIMITTAJA VUOSINA \\ 2010-2018 \\ Valtiotieteiden tohtori Heikki \\ Silvennoinen on professori Turun \\ yliopistossa.
}

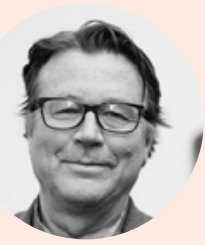

1 Päällimmäisenä mielessäni on aihepiireiltään ja tutkimuskohteiltaan erittäin monipuolinen artikkelikattaus. Aiheet ja näkökulmat vaihtelivat laidasta laitaan, mikä on kiinnostavan ja ennakkoluulottoman lehden merkki. Kun artikkeli vain täyttää tieteellisyyden kriteerit, lähestymistavan, tutkimusotteen tai menetelmien vuoksi sitä ei suljeta ulos.

Työelämän ja osaamisen teemat olivat vahvasti esillä, mutta usein puhuttiin yleisemminkin sivistyksestä ja esimerkiksi kansalaisten osallisuudesta. Tuolloin esiin puskeneet globaalin vastuun kysymykset ja planetaariset huolet, kuten ekososiaalisen sivistyksen teemat ja konsumeristisen elämäntavan kritiikki, vahvistunevat edelleen.

2 Halusin lisätä keskustelua aikuiskasvatuksesta tieteenalana ja alan tutkimuksesta. Julkaisulla oli tulossa täyteen 30 vuotta, ja halusimme sekä juhlistaa merkkivuotta että herätellä keskustelua aikuiskasvatuksesta monitieteisenä tutkimusalana. Silloin, kuten nytkin, monimutkaiset yhteiskunnalliset ongelmat tuntuivat tarvitsevan monitieteisiä lähestymistapoja. Käynnistin tieteenalan tilasta ja suunnasta kirjoitussarjan, jonka avasivat emeritusprofessori Ari Antikainen ja tuolloin Helsingin yliopistossa tutkijana toiminut Kristiina Brunila. Kirjoitimme toimituskunnan voimin puheenvuoron "Aikuiskasvatustieteen tila ja tulevaisuus", minkä jälkeen useat alan professorit osallistuivat keskusteluun omilla puheenvuoroillaan.

Pääkirjoituksissa otin aikuiskasvatuksen tutkimusteemat useinkin esille ja pohdin alan tutkimustarpeita.

Toimituskunnan kokouksissa keskustelimme tieteenalan problematiikasta, lähestymistavoista, metodologiasta ja teoretisoinneista käsitellessämme käsi- kirjoituksia. Keskustelujen pohjalta kirjoittajia tuettiin ohjeilla ja parannusehdotuksilla. Uskon vahvasti, että keskusteleva julkaisuprosessimme paransi tiedeartikkeleiden laatua.

3 Aikuiskasvatustiede kattaa laajasti kaiken sen toiminnan, jolla aikuisiin ihmisiin vaikutetaan ja yritetään vaikuttaa. Yksi näistä vaikutuskeinoista, koulutus, on julkisen vallan erityisessä suojeluksessa mutta toki vain yksi muoto, jolla ihmisten ajatteluun ja käyttäytymiseen vaikutetaan. Nykyisin vaikutusyritykset ja vaikuttamisen keinot ovat yhä monimuotoisempia, kyseenalaisiakin tai jopa tietoisesti harhaanjohtavia. Tutkimus on tässä mielessä jopa aiempaa tärkeämpää. Aikuiskasvatus on foorumi tämän todellisuuden tutkimukselle ja sen koonnille.

\section{PÄÄTOIMITTAJAN VALINTA}

Useissa teksteissä on tärkeitä näkemyksiä, huomioita ja näkökulmia tieteenalan itseymmärrykseen enkä suostu nostamaan esiin yhtä ainoaa vaan kehotan lukemaan neljä artikkelia, jotka ovat vuorovaikutuksessa keskenään, muodostavat kokonaisuuden ja kuvastavat kokeneen tutkijan asiantuntemusta. Kokonaisuudessa tulevat esiin historiallinen ulottuvuus, nykytila ja tulevaisuus.

Antikainen, A. (2010). Onko aikuiskasvatustutkimus käännekohdassa? Aikuiskasvatus 30(2), 130-137. https://doi. org/10.33336/aik.93870

Rinne, R. (2010). Historiallinen murros ja aikuiskasvatuksen tutkimus. Aikuiskasvatus 30(4), 250-255. https://doi.org/10.33336/ aik.93893

Filander, K., Jauhiainen, A., Onnismaa, J., Saloheimo, L., Silvennoinen, H. \& Valkama, H. (2010). Aikuiskasvatustieteen tila ja tulevaisuus. Aikuiskasvatus 30(3), 213223. https://doi.org/10.33336/aik.93884

Heikkinen, A. (2012). A-luokan aikuiskasvatustiedettä. Aikuiskasvatus 32(1), 50-58. https://doi.org/10.33336/ aik.93969 


\section{"Avoin julkaiseminen parantaa näkyvyyttä ja edistää keskustelua"}

\author{
PETRI SALO \\ PÄÄTOIMITTAJA VUOSINA \\ 2007-2009 \\ Kasvatustieteen tohtori \\ Petri Salo on professori Åbo \\ Akademissa.
}

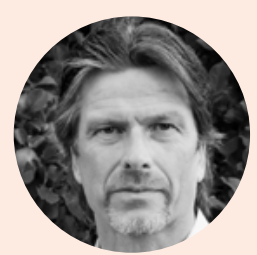

1 Päätoimittajakaudellani esillä olivat ammatillinen kasvu ja kehitys sekä näihin liittyen asiantuntijuus ja yrittäjyys. Samoin kaudellani korostui omana teemanaan "aikuisopiskelijat yliopistossa".

2 Aikuiskasvatuksesta tieteenalasta ei kaudellani käyty erikseen keskustelua, ja keskusteluakin ylipäätään käytiin hyvin vähän. Ainoa mieleeni tuleva keskustelu koski johtamiskoulutuksen tieteellisyyttä. Nyky-yliopistot ovat tuotantolaitoksia, joissa keskitytään hankkimaan ulkopuolista rahoitusta sekä tuottamaan tutkintoja ja tieteellisiä artikkeleja. Tieteellisen keskustelun käymisestä ei palkita.

3 Aikuiskasvatusta tarvitaan risteysasemaksi, kohtauspaikaksi ja toriksi, jolle tullaan esittämään asioita, kuuntelemaan, puhumaan, provosoimaan ja provosoitumaan toisia kunnioittaen ja ymmärtämään pyrkien. Toiminta risteysasemalla perustuu tieteen lähtökohtiin ja menetelmiin ja nojaa mielellään empiiriseen tutkimukseen. Muotoilin tieteenalan tehtävän ensimmäisessä pääkirjoituksessani, ja se pätee yhä: "Hahmotan edustamani aikuiskasvatuksen tietyistä perinteistä ja rakentavasta ihmiskuvasta voimansa ammentavaksi ihmis- ja yhteiskuntatieteiden kohtauspaikaksi. Edistääksemme aikuiskasvatuksen tutkimusta ja monimuotoisia käytäntöjä sekä niiden välistä vuoropuhelua meidän on kyettävä kohtaamaan toisemme ja keskustelemaan. Keskustelun avaamiseksi ja ylläpitämiseksi tarvitsemme yhteisen ja ymmärrettävän kielen. Lisäksi meidän on kyettävä provosoimaan ja provosoitumaan, ei kuitenkaan kanssatutkijoita tai -ihmisiä ainoastaan kyseenalaistaen vaan heidän ajatuksiaan kunnioittaen ja ymmärtämään pyrkien.”

On tarkoituksenmukaista, että Aikuiskasvatus on avoin verkkojulkaisu, jossa tutkimustieto on helposti kaikkien saatavilla. Lisäksi opetus- ja kulttuuriministeriö palkitsee tutkijoita avoimesta julkaisemisesta, eli tiedeartikkelista julkaisuissa, jotka ovat kaikkien saatavilla.

\section{PÄÄTOIMITTAJAN VALINTA}

Monista mielenkiintoisista esimerkeistä nostan esiin professori Jyri Mannisen artikkelin "Sopeuttavaa sivistystyötä" vuodelta 2010. Siinä avataan empiirisesti vapaan sivistystyön "musta laatikko", eli tutkitaan osallistumisen ja oppimisen vaikutuksia, sekä hyödynnetään teoreettista viitekehystä, joka kokoaa monen tutun aikuiskasvatuksen tutkijan orientaation oppimiseen ja muutokseen. Lukemisen perusteella voi, kysyä onko tämänhetkinen suomalainen jatkuvan oppimisen näkökulma yksilöllistä sopeutumista myötäilevä.

Jos on, niin mitä siitä seuraa globaalia pandemiaa ja ilmastonmuutosta ajatellen?

Manninen, J. (2010). Sopeuttavaa
sivistystyötä?. Aikuiskasvatus 30(3), 164-
174. https://doi.org/10.33336/aik.93879 
1 Mitkä teemat korostuivat päätoimittajakaudellasi? 2 Miten edistit päätoimittajakaudellasi tieteenalasta käytävää keskustelua? 3 Mihin Aikuiskasvatus-lehteä tarvitaan?

\section{"Paikallisten ja planetaaristen perspektiivien yhdistäminen vaatii julkaisulta uudistumista"}

\author{
ANJA HEIKKINEN \\ PÄÄTOIMITTAJA VUOSINA \\ 2001-2006 \\ Kasvatustieteen tohtori, \\ filosofian maisteri Anja \\ Heikkinen on professori emerita \\ Tampereen yliopistossa.
}

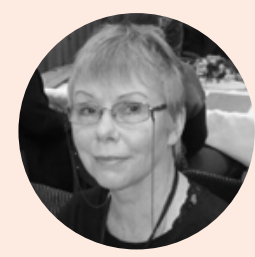

1 Päätoimittajanvuosinani elettiin niin käytännön ja politiikan kuin tieteen kannalta varsin nosteisissa oloissa. Esimerkiksi parlamentaarinen aikuiskoulutustyöryhmä teki elvyttäviä ehdotuksia kaikille aikuiskasvatuksen aloille. Lisäksi olivat kansalaisvaikuttamisen politiikkaohjelma ja Vapaan sivistystyön osaaminen ja pätevyys -ohjelma (VSOP), jotka rohkaisivat vapaata sivistystyötä, sen tutkimusta ja koulutusta. Noste-ohjelma resursoi mittavasti ammatillista aikuiskoulutusta, Koulutuksen arviointineuvosto taas teki näkyväksi aikuiskasvatuksen, -koulutuksen ja aikuiskasvattajuuden tilaa ja kehittämistarpeita.

Yliopistoissa aikuiskasvatukseen profiloituneet virat ja koulutusohjelmat olivat vahvoilla, ja ammattikorkeakouluja rakennettiin kiivaasti. Tematiikan saaminen lehteen vaati aktiivista yhteydenpitoa eri kenttien toimijoiden kanssa. Spontaanisti lehteen tarjotuissa artikkeleissa näkyivät ammattikorkeakoulun opettajien tieteellisen pätevöitymisen paineet, hiukan myös yleisen kasvatustieteen tutkijoiden meritoitumispyrkimykset.

2 Olin siltä kannalta onnekas, että aikuiskasvatuksen politiikkaa, käytäntöä ja tutkimusta käsitteleviä tieteellisiä artikkeleita, katsauksia ja puheenvuoroja tuotiin todella aktiivisesti keskusteluun, ja mukana oli monipuolisia keskustelijoita alan professoreja myöten. Lehden rakenteen selkiyttäminen tiedeartikkeleiksi, näkökulmiksi tutkimukseen, politiikkaan ja käytäntöön, keskusteluiksi ja puheenvuoroiksi sekä kirja-arvioiksi edisti osaltaan asiaa.

Tietyt teemat, kuten aikuiskasvatuspolitiikka, käytännön ja tieteen itseymmärrys, aikuisten oppiminen, opetus ja kasvattajuus, toistuvat vuodesta toiseen. Ha- lusin kannustaa aikuiskasvatuksen valtavirtaa kyseenalaistavaa ja itsekriittistä keskustelua. Uusia avauksia olivat kysymykset aikuiskasvatuksen sukupuolittavasta luonteesta, pinnallisesta suhteesta luontoon ja teknologiaan, työhön ja talouteen sekä tunteiden ja sosiaalisuuden merkityksestä. Omat ajatukseni olisivat olleet paljon ärhäkämpiä, mutta pidin parempana, että keskustelu näyttäytyy lehdessä sen tosiasiallisen tilan eikä omien toiveitteni mukaisena.

3 Ennakoimattomasti muotoilluilla julkisuuden ja viestinnän markkinoilla tiedelehden tarpeellisuutta ja tehtävää on aika toivotonta määritellä. Kyse on yleisemmin yliopiston, tieteen ja tutkimuksen yhteiskunnallisesta asemasta ja tehtävästä. Niiden sivistyksellinen autonomia ja eetos - vastuu ja vapaus - riippuvat yliopiston ja tiedeyhteisön omasta, itsekriittisestä harkinnasta. On sääli, jos hitaat ja argumentoivat, tieteen, politiikan ja käytännön toimijoita kohtauttavat foorumit luovuttavat blogien ja vlogien aikakaudella. Aikuiskasvatuksen paikallisten ja planetaaristen perspektiivien väistämätön yhdistäminen edellyttänee lehdeltä kuitenkin uudenlaisia kielellisiä ja toiminnallisia ratkaisuja.

\section{PÄÄTOIMITTAJAN VALINTA}

Seppo Niemelä oli intomielinen aikuiskasvatuksen teoreetikko, poliittinen ja käytännöllinen vaikuttaja ja uskollinen Aikuiskasvatukseen kirjoittaja. Väittelin lukemattomat kerrat hänen tulkinnoistaan, jotka koskivat vapaan sivistystyön ja aikuiskasvatus-oppiaineen kehitystä, hänen poliittisten visioittensa utopistisuudesta ja olettamastani naiiviudesta - etenkin uskossa Euroopan unionin aikuiskoulutuspolitiikan sivistykselliseen ja demokraattiseen potentiaaliin. Niemelän kirjoitusten myötätuntoisen kriittinen luenta tekisi hyvää kaikille aikuiskasvatustieteen rakentumisesta ja itseymmärryksestä kiinnostuneille.

Niemelä, S. (2002). Kansansivistyksen

kadottaminen. Aikuiskasvatus 22(2), 84-91.

https://doi.org/10.33336/aik.93404 
1 Mitkä teemat korostuivat päätoimittajakaudellasi? 2 Miten edistit päätoimittajakaudellasi

tieteenalasta käytävää keskustelua? 3 Mihin Aikuiskasvatus-lehteä tarvitaan?

\section{aikuiskoulutuksen ammattilaisia työssään"}

\section{KAUKO HÄMÄLÄINEN \\ PÄÄTOIMITTAJA VUOSINA \\ 1992-1997}

Kasvatustieteen tohtori Kauko Hämäläinen on professori

emeritus Helsingin yliopistossa.

1 Kauteni alussa linjasimme leh-

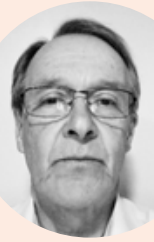

teä siten, että aikuiskoulutuksen arvoperusteiden, tavoitteiden ja toimintaperiaatteiden pohdinta ja osallistuminen aikuispoliittiseen keskusteluun korostuivat. Aikuisten oppimista ja kouluttamista haluttiin tukea välittämällä tutkimuspohjaisia käytännön kokemuksia ja tuoda siten uusia ideoita aikuiskasvatuksen kentälle. Tutkimuksen ohella tuotiin esille kokeilu- ja kehittämistoimintaa eli välitettiin hyviä käytänteitä.

Suomalaisen osaamisen ohella välitimme osaamista ulkomailta. Kansainvälisen yhteistoiminnan esittelyä ja arviointia ja muiden maiden aikuiskoulutuspolitiikan ja käytännön kokemusten esittelyä pidettiin tärkeänä.

Vuosikymmenestä toiseen jatkunut teema on aikuiskoulutuksen merkityksen jatkuva kas- vu. Yleisinä kvalifikaatioina painotettiin edelleen oppimaan oppimista, kommunikointitaitoja sekä muutoksen sietokykyä ja hallintaa. Jatkuvan oppimisen merkitystä elämän mielekkyyden ja yksilön hyvinvoinnin kannalta korostettiin. Ohjaus, digitalisointi ja opetuksen tehostamistavat ovat olleet jatkuvasti mielenkiinnon kohteena. Monia liike-elämästä liikkeelle lähteneitä ajatusvirtauksia on tuotu esille, esimerkiksi oppiva organisaatio ja laatujohtaminen.

Aikuiskoulutuksen rahoitus on ollut lehdessä yhtäältä pohdinnan kohde, toisaalta koulutustoimintaa ohjaava tekijä. Esimerkiksi 1990-luvun lamassa vapaa sivistystyö ja ammatillinen täydennyskoulutus olivat vaikeuksissa. Koulutusmaksut nousivat merkittävästi, mutta osallistujamäärät eivät juurikaan laskeneet merkittävästi.

2 Päätoimittajan osaaminen ja mielenkiinnon kohteet ohjaavat jossain määrin lehtien teemojen ja kirjoittajien valintaa. Omia intressejäni olivat koulutuksen ja koulutusorganisaatioiden laatu, koulutuksen vaikuttavuus ja ammatillinen täydennyskoulutus, joista kokosimme teeman (3/1993). Se toi esiin, mitä laadun arvioinnilla on ymmärretty Suomessa, mihin se on kohdistunut ja miten arvioinnit on to-

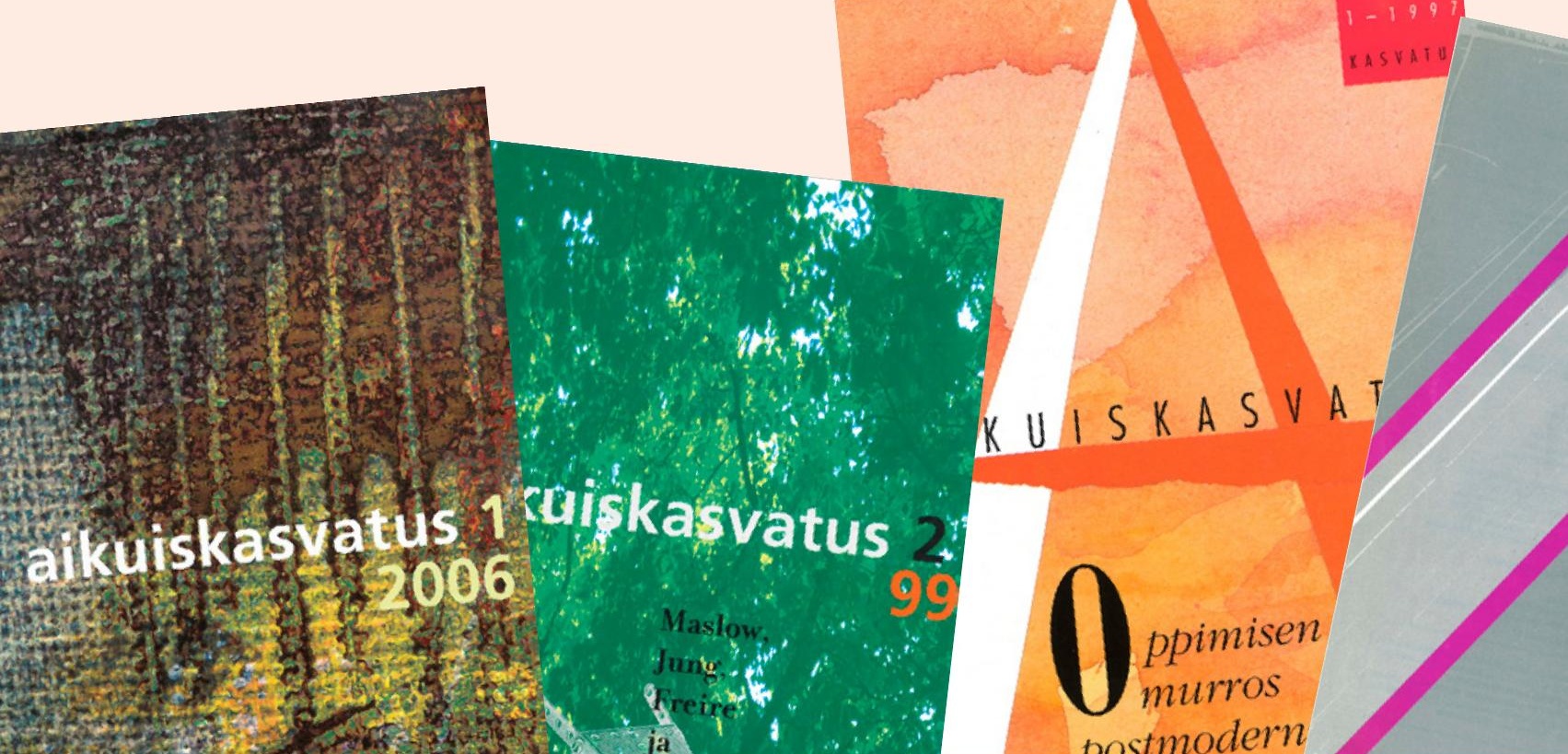


1 Mitkä teemat korostuivat päätoimittajakaudellasi? 2 Miten edistit päätoimittajakaudellasi

tieteenalasta käytävää keskustelua? 3 Mihin Aikuiskasvatus-lehteä tarvitaan?

teutettu. Esimerkiksi Reijo Raivio pohdiskeli koulutuksen merkitystä taloustieteen näkökulmasta ja Ritva Jakku-Sihvonen tuloksellisuuden käsitettä valtakunnallisen vaikuttavuuden kannalta.

3 Tieteenalalla ja lehdellä on merkittävä tehtävänsä teoriatiedon ja käytännön yhdistäjänä. Aikuiskasvatustieteen tulee tuottaa tietoa, jolla on merkitystä aikuiskasvatuksen ammattilaisille. Siinä Aikuiskasvatus poikkeaa muista tiedelehdistä. Päätoimittajakaudellani lehden tilaajat edustivat monipuolisesti esimerkiksi noin tuhatta siihen aikaan toiminutta aikuiskoulutusorganisaatiota. Lukijoissa oli siten runsaasti henkilöitä tutkijayhteisön ulkopuolelta.

Lehden tehtävänä oli - ja yhä on - palvella kansansivistystehtävissä, henkilökoulutuksen parissa työskenteleviä ja muita aikuiskoulutuksen suunnittelijoita ja koulutuksen toteuttajia ja arvioijia. Yksi keskeinen tehtävä on teoreettisesti perusteltujen hyvien käytänteiden välittäminen aikuiskoulutuksen ammattilaisille. Esimerkiksi toimintatutkimukseen tai vastaaviin lähestymistapoihin perustuvia hankkeita on mielenkiintoista ja hyödyllistä esitellä.

\section{PÄÄTOIMITTAJAN VALINTA}

Professori Tapio Vahervan artikkeli täyttää monia lehden tavoitteiksi määriteliämme asioita. Vaherva oli 1980-luvulta lähtien yksi eniten referoitu tutkija puhuttaessa koulutuksen arvioinnista. Hän tutki henkilöstökoulutuksen vaikuttavuutta organisaation kehittymiselle kahden tapauksen avulla. Vuosien mittaisten interventioiden vaikutuksia seurattiin monipuolisilla menetelmillä toimintatutkimuksen periaatteita noudattaen. Viisivuotisten projektien vaiheita kuvataan tarkasti, ja ratkaisuja perustellaan teoreettisesti. Henkilöstökouluttajien kouluttajana Vaherva on pystynyt myös välittämään osaamistaan laajasti yhteiskunnalle.

Vaherva, T. (1992). Työelämän aikuiskoulutusta arvioimassa. Aikuiskasvatus 12(3), 136140. https://doi.org/10.33336/aik.96821

Juttuun haastateltujen päätoimittajien lisäksi Aikuiskasvatusta ovat päätoimittaneet Tampereen yliopiston professorit Jukka Tuomisto vuosina 1981-1991 ja Reijo Raivola vuosina 1998-2000.

Aikuiskasvatus täyttää 40 vuotta. Juhlavuotena lehdessä julkaistaan katsauksia tieteenalaan eri näkökulmista.

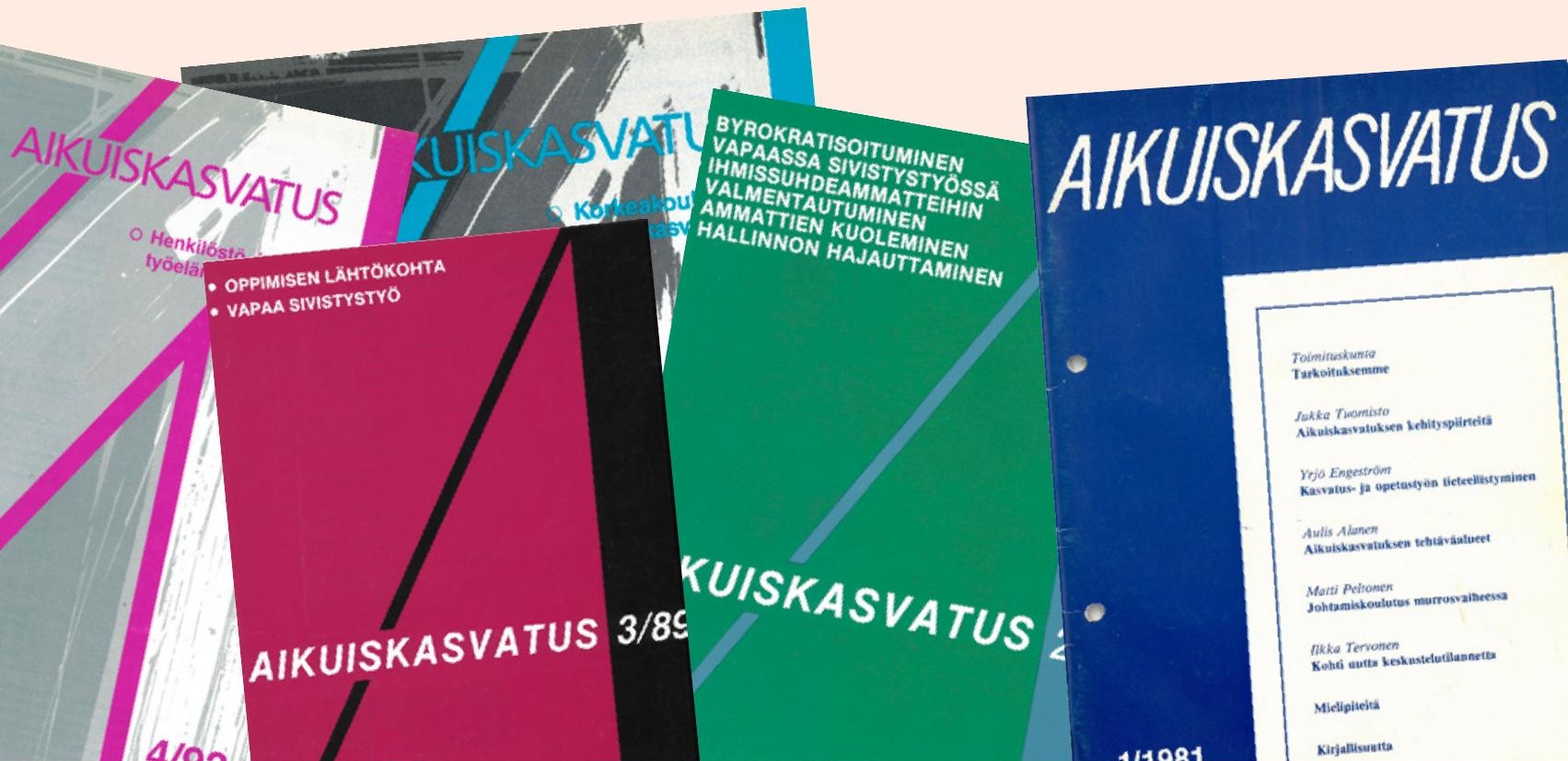

